\title{
Formulation, Development and Quality Assessment of Nutri- Rich Snack Food (Sev)
}

Surendra Kumar Patel ${ }^{1}$, M A Khan², Gajendra Kumar Rana ${ }^{3}$, Mayank Mehra ${ }^{4}$

10.18805/ajdfr.DR-1460

\begin{abstract}
The study was carried out in the Department of Food Science and Technology, JNKVV, Jabalpur, MP, India, with the objectives to develop the Nutri-rich snack food (Sev) based on Minor Millet, (Kodo) and to evaluate the sensory and nutritional quality of the product. Chickpea and soybean is an important legume with a rich source of protein and dietary fiber. Millets are nutritionally superior to other cereals. Minor millet Kodo is a nutritious millet with the highest dietary fiber (14.3\%) makes it ideal food. On the basis of present findings it was concluded that $\mathrm{S}_{3}$ (60:20:20 ratio of chickpea, Kodo and soy flour) was highest acceptable with respect to all sensory attributes like colour and appearance, taste, flavor, texture and overall acceptability and physical characteristics of final product with the nutritional value of carbohydrates, protein, ash, fat and crude fibre with the percentage of 52.16, 25.06, 2.80, 8.80 and 5.0 respectively. Functional properties are directly related to the quality of the final product. In the present investigation, the high content of oil in the blends having a high ratio of soy flour may develop off-flavor. Thus it could not be used beyond 20 percent.
\end{abstract}

Keywords: Assessment of quality, Kodo millets, Nutri-rich snacks (sev), Soybean

Asian Journal Of Dairy and Food Research (2019)

\section{INTRODUCTION}

" C ev" is one of the popular Indian traditional deep fat fried snack food (Pruthi et al.; 1983). Traditionally, it is prepared from Bengal gram flour (besan) with additives such as salt, spices, and sodium bicarbonate; various other additives are also added to impart crispy and crunchy texture organoleptic appeal and to increase the physical condition of the fried product (Berry et al.; 1986). The appeal and consumption of snack food are increasing once daily; consequently, there is a need to increase the production of more nutritious and cost-effective snacks.

Sev is essentially small pieces of crunchy noodles. It is a popular variety of Indian snack food. Sev can be made with whole Bengal gram flour and rice flour mix at home and stored for weeks in airtight containers. Sev is a popular extruded, fried snack in India made from chickpea (Cicer arietinum L.) flour dough containing pepper, cumin, and ajowan as a flavorant (optional) and is relished for its texture and aroma. It is an established snack food in various part of our country, high cost of raw material, i.e. Bengal gram flour contributes towards the final cost of the furnished product, which limits its marketing.

Minor millets are claimed to be future foods for better health and nutrition security in the recent years, they are recognized as important substitutes for major cereal crops to cope up with the world food shortage and to meet the demands of the increasing population (Rachie, 1975).

Soybean is associated with anti-nutritional factors such as trypsin inhibitors and ham agglutinins in addition to others. Heat treatment inactivates anti-nutritional factors such as trypsin inhibitors and ham agglutinins (Singh et al. 1993).

\section{Material and methods}

\section{Processing of Foodgrains}

Chickpea (Cicer arietinum), Kodo (Paspalum scrobiculatum), soybean (Glycine max) were procured from the local market of Adhartal, Jabalpur.

\footnotetext{
1,2Department of Food Science and Technology, Jabalpur 482004, Madhya Pradesh, India

${ }^{3}$ Krishi Vigyan kendra Seoni, Madhya Pradesh, India

${ }^{4}$ Krishi Vigyan kendra, Sagar, JNKVV, Jabalpur 482004, Madhya Pradesh, India
}

Corresponding Author: Surendra Kumar Patel, Department of Food Science and Technology, Email: sp5097527@gmail.com

How to cite this article: Patel, S.K., Khan, M.A., Rana, G.K. and Mehra, M. (2019). Formulation, Development and Quality Assessment Of Nutri-Rich Snack Food (Sev). Asian Journal Of Dairy and Food Research, 38(3): 257-260.

Source of support: Nil.

Conflict of interest: None

Submitted:02-07-2019 Accepted:14-09-2019 Published: 01-11-2019

\section{Preparation of flours}

Grains were thoroughly cleaned to remove dirt, stone, dust, wood, insect excreta/ feathers, and admixture of other food grains. The clean graded materials were ground in the electric grinder to make flour of the required size.

\section{Preparation of blends}

In Table 1 different formulations of sev fortified with soy and Kodo flours are shown.

\section{Preparation of sev}

Sev blends were prepared after the addition of oil, water, salt, and all ingredients (Table 2) in 100 gram of mixed flour. All the ingredients were taken in a plastic bowl mixed and kneaded well with had by addition of water. The quantity of water added was adjusted to such a level that finally kneaded dough was pliable. The dough was then extruded through 
Table 1: Different formulations of sev fortified with soy and Kodo flour

\begin{tabular}{lllll}
\hline $\begin{array}{l}\text { S. } \\
\text { No. }\end{array}$ & Treatments & $\begin{array}{l}\text { Chickpea } \\
\text { flour (\%) }\end{array}$ & Soyflour (\%) & $\begin{array}{l}\text { Kodo flour } \\
(\%)\end{array}$ \\
\hline 1 & $\mathrm{~S}_{0}$ (control) & 100 & - & - \\
2 & $\mathrm{~S}_{1}$ & 80 & 10 & 10 \\
3 & $\mathrm{~S}_{2}$ & 70 & 15 & 15 \\
4 & $\mathrm{~S}_{3}$ & 60 & 20 & 20 \\
5 & $\mathrm{~S}_{4}$ & 50 & 25 & 25 \\
\hline
\end{tabular}

a manually operated sev press directly into a frying pan containing about one liter of double filtered, refined soybean oil maintained at $180{ }^{\circ} \mathrm{C}$ (approximate) after completion of frying sev were taken out of pan and held above the oil to allow the excess oil to drain back into the pan.

\section{Physical properties}

\section{Yield of sev}

The final yield of deep fat fried sev was measured and calculated as the total product obtained by the total blend used expressed as $\mathrm{gm} / 100 \mathrm{gm}$.

\section{Diameter}

The diameter/thickness of the product was measured using a thickness meter, and an average mean of 10 values was reported and expressed as a millimeter.

\section{Frying time}

The time taken by sev for cooking measured using a stopwatch and expressed in seconds.

\section{Functional properties of sev mixes}

Fat absorption capacity (FAC)

Fat absorption capacity was measured by the method of Sosulski et al., (1976).

\section{Water absorption capacity (WAC)}

The methods of Sosulski et al.,1976 measured water absorption capacity.

\section{Proximate composition of sev mixes}

The moisture content of the sample was determined by the using moisture meter. Protein, fat, ash and crude fiber was determined according to the procedure given in
Table 2: Important ingredients

\begin{tabular}{lll}
\hline S. No. & Ingredients & Quantity $(\mathrm{g} / 100 \mathrm{~g}$ flour mixes) \\
\hline 1 & Red chili powder & 1.0 \\
2 & Turmeric powder & 0.4 \\
3 & Black pepper & 0.4 \\
4 & Salt & 3.0 \\
5 & Oil & $5 \mathrm{ml}$ \\
6 & Cumin seed & 3.0 \\
7 & Water & As required \\
\hline
\end{tabular}

Association of Official Agricultural Chemists (AOAC) 1992, and Carbohydrates was estimated by acid hydrolysis method as described by Hassid and Abraham (1965).

\section{Sensory evaluation of products}

The sensory quality characteristics of the products such as color, taste, texture, flavor, and overall acceptability were evaluated by a panel of judges using nine-point hedonic scales as described by Amerine et al. (1965).

\section{Statistical Analysis}

The complete data is presented as mean \pm SED of four replicates. The nutritive values of sev were subjected to analysis of variance (ANOVA) to distinguish the responses of different levels of substitution and performed using complete randomized design (CRD). The levels of significant differences are reported as $\mathrm{p} \leq 0.05$, and it is described as Panse and Sukhatme (1963).

\section{Results and discussion}

\section{Optimization}

Sev prepared from the combination of $\mathrm{S}_{3}(60 \%$ Chickpea flour $+20 \%$ Soy flour and $20 \%$ Kodo flour) were found to highest acceptable texture as compare to other samples. This may be due to incorporation of different soy and Kodo millet flour in appropriate combination. The ingredients of sev standardized by Geetalakshmi and Prakash, (2000) are in contrast with the present study.

Table 3 clearly indicated that $\mathrm{S}_{3}(60 \%$ Chickpea flour $+20 \%$ Soy flour and $20 \%$ Kodo flour) recorded highest fat absorption capacity. Increase in fat absorption capacity may be due the addition of pulse flour in sev. The similar value was reported by Nath and Narsing Rao (1981) for soya meal and higher value reported by Tasneem et al., 1982 with regard to soya

Table 3: Proximate analysis of sev mixes:

\begin{tabular}{llllllll}
\hline S. No. & Treatment & $\begin{array}{l}\text { Moisture } \\
\text { content (\%) }\end{array}$ & Carbohydrate (\%) & Protein (\%) & Ash (\%) & $\begin{array}{l}\text { Crude Fiber } \\
\text { Fat (\%) }\end{array}$ \\
\hline 1 & S0 & 8.48 & 60.44 & 20.68 & 3.00 & 4.20 & 3.2 \\
2 & S1 & 6.86 & 58.04 & 23.40 & 2.40 & 5.80 & 3.5 \\
3 & S2 & 6.77 & 53.86 & 24.27 & 2.80 & 7.80 & 4.5 \\
4 & S3 & 6.18 & 52.16 & 25.06 & 2.80 & 8.80 & 5.0 \\
5 & S4 & 5.98 & 49.07 & 26.65 & 2.60 & 10.20 & 5.5 \\
6 & SEm \pm & 0.050 & 0.513 & 0.058 & 0.057 & 0.068 & 0.051 \\
7 & CD at 5\% & 0.159 & 1.616 & 0.183 & 0.181 & 0.215 & 0.162 \\
\hline
\end{tabular}


flour. Heat processing increased the fat absorption capacity of different pulse flour blends used in sev preparation. This increase could be due to both dissociation of proteins that may occur on heating and also denaturation which is expected to unmask the non polar residue from the interior of the molecules. Since the products based on pluses absorbed lesser fat on thermal treatment, it can be concluded that it did not affect the textural quality adversely. The similar result reported by Geethalakshmi and Prakash (2000).

\section{Physical characteristics of sev}

\section{Frying time}

Frying time indicates the quality of initial ingredients used and the final product obtained. An increase in frying time shows the capacity of flour to absorb more moisture and oil. The result obtained interprets that Kodo and soy flour required more time to fry as compare to chickpea flour.

\section{Yield of the product}

It appears that whenever the proportion of Kodo and soy flour increased the yield of the product also increased. Thus the proportion of Kodo and soy flour was the main facto responsible for increase in yield. It show that water and fat absorption capacity of Kodo and soy flour was higher than the of chickpea flour.

\section{Diameter of sev}

Diameter of sev can be explained on the basis of water and fat absorption capacity of flour. As Kodo flour was found to have maximum water and fat absorption capacity and it is responsible for more diameter of the product. The higher bulk density of ingredients incorporated in modified mixes. However the findings of Singh et al., 2003 are in contrast with the present findings.

\section{Water uptake:}

It depends on the chemical characteristics of the particular flour. The requirement of amount of water varied with the types of the flour used for preparation of sev.

\section{Oil uptake}

The oil absorption in the sev during frying was increase with amount of soy flour was decrease. The more absorption of oil by the sev from chickpea, Kodo and soy flour could be easily justified on the basis of the related observation on water absorption capacity and fat absorption capacity, and yield of the product.

\section{Proximate composition of sev mixes}

The moisture content of sev in which chickpea flour was used had higher moisture content, indicates that the chickpea flour was responsible for it. The variation in moisture content of sev seems to be due to difference in water absorption capacity of various proportions of flour for making dough. There were also variations in frying time. These results were well supported by Kulkarni et al.,1994.

\section{Protein}

In different blends was found to decrease with increase of chickpea flour. This reduction in protein content could be correlated with higher oil absorption during frying time as well as low amount of protein content in chickpea and Kodo used for fortification. Several investigations also (Pruthi et al., 1983; and Kulkarni et al. 1994) reported that this was due to low protein content in various type of cereals and millets flour used for preparation of sevian product. These results support the present findings. As can be seen from the Table 3 gradual increase in the protein and fat will be increase and decrease in moisture and ash with modification was observed in sev mixes and sev. This may be due to addition of soy and Kodo flour in modified recipe. The similar results are reported by Dhore (2011). Senthil et al., (2002), Veena et al., (2004) the findings of present study are in contrast with the finding of Chouhan and Tomar (1998) with regards to soya snacks. The nutrient content of sev was found to more as compare to flour mixes. This may be attributed to evaporation of moisture during frying. However, the increase in fat content was much higher due to absorption of fat during frying Geethalakshmi and Prakash (2000).

\section{Overall acceptability of sev}

Overall acceptability is depending on the sensory evaluation of the product. The supplementation of soy and Kodo flour (over the 20:20) decreased the sensory quality characteristics of the developed sev. The data reveals that as the ratio soy and Kodo flour increased in the dough, the sensory attributes viz., taste, flavor, colour, and texture increased up to the level of 60:20:20 (Chickpea: Soy:Kodo) and then decreased. Different spices used in the product showed significant differences among each other. The flour ratio and spices had significant effect on the quality of the product. On the basis of sensory evaluation of $\mathrm{S}_{3}$ blend was considered the best as compare to other. The crisper texture in the products with added fat enhanced the acceptability scores. The similar result reported

Table 4: Sensory attributes of sev

\begin{tabular}{lllllll}
\hline S. No. & Treatment & Color and appearance & Taste & Texture & Flavor & Over all acceptability \\
\hline 1 & S0 & 7.90 & 8.20 & 8.10 & 8.40 & 8.15 \\
2 & S1 & 8.50 & 7.55 & 7.90 & 7.80 & 7.93 \\
3 & S2 & 7.40 & 8.95 & 8.00 & 7.70 & 8.01 \\
4 & S3 & 8.70 & 8.30 & 8.30 & 8.60 & 8.50 \\
5 & S4 & 7.50 & 0.096 & 0.080 & 8.35 & 8.00 \\
6 & SEm \pm & 0.066 & 0.302 & 0.261 & 0.051 & 0.063 \\
7 & CD at 5\% & 0.210 & & & 0.162 & 0.201 \\
\hline
\end{tabular}


by Geetalakshmi and Prakash (2000). Findings of Deepa et al., 1992 regarding the addition of $30-40 \%$ soybean flour in prepared are in contrast with the present findings, whereas results of Dhore (2011) are similar to the present study.

\section{Functional properties of mixed sev flour}

The present investigation was carried out to prepare sev using mixed flours having different flours. Studies of water absorption capacity of proteineous material are useful in assessing potential food application products. The water absorption capacity was found to be maximum in formulation $\mathrm{S}_{4}(50 \%$ Chickpea flour $+25 \%$ Soy flour and $25 \%$ Kodo flour) and $\mathrm{S}_{3}(60 \%$ Chickpea flour $+20 \%$ Soy flour and $20 \%$ Kodo flour). Water absorption capacity was increased due to addition of different pulse flour. Similar finding were reported by Dhawan et al. (1998), Senthil et al. (2002) in with regards to soy flour incorporated. Denaturation of protein, the interaction of components, and structural damage to starch on heating lead to higher water absorption capacity in pulse flours (Deoskar, 2004). Carbohydrates present in flour may play a role in water absorption capacity. During heat gelatinization of carbohydrate, swelling of crude fiber may occur, which could also increase water absorption capacity. The findings are well collaborated by the reported values of Bhatt et al. (2003).

\section{Conclusion}

The study was carried out to enhance the utilization of Kodo and soy flour as well as the development of better quality sev with lesser cost. As the sev is essentially small pieces of crunchy noodles and it is a popular variety of Indian snack food. Sev can be made with whole Bengal gram flour and rice flour mix at home and stored for weeks in airtight containers. On the basis of present findings it was concluded that $S_{3}$ (60:20:20 ratio of chickpea, Kodo and soy flour) was highest acceptable with respect to all sensory attributes like colour and appearance, taste, flavor, texture and overall acceptability and physical characteristics of final product with the nutritional value of carbohydrates, protein, ash, fat and crude fibre with the percentage of 52.16, 25.06, 2.80, 8.80 and 5.0 respectively. Functional properties are directly related to the quality of the final product. In this investigation, high content of oil in the blends having a high ratio of soy flour may develop off-flavor. Thus it could not be used beyond 20 percent.

\section{References}

AOAC (1992). Official methods of analysis $16^{\text {th }}$ edition. Association of official Analytical Chemists Inc., Arlington VA.

Amerine, M. A. Pangborn, R. M. and Roessler, E B. (1965). Principle of sensory evaluation of foods, Academic Press, New York, 349.

Berry, S. K. Kulkarni, S. G. Senghal R. C. Kaur, S. and Kalra C. L. (1986). Studies on the utilization of post cold stored potatoes in the preparation of potato besan 'sevian'. Indian Food Packer 40: 42-49.
Bhatt, A. Singh, V. Shrotria, P. K. and Baskheti, D. C. (2003). Coarse grains of Uttaranchal: Ensuring sustainable food and $\mathrm{N}$ nutritional security. Indian Farmer's Digest 34-38.

Chauhan, G.S. and Tomar, N. S. (1998). Varietal effect on the quality of fried snacks. Journal of Food Science and Technology 35: 171.

Deepa, C. R. Asna, U. and Shashikala, P. (1992). Effect of addition of soy flour on the quality characteristics of black gram (Phaseolus mungo L.) papads. Journal of Food Science and Technology 29 (6): 385-387.

Deoskar, A. and Shastri P. N. (2004). Changes in structural, fat binding and water absorption of starch during roasting of wheat and legume flours. Journal of Food Science and Technology 41 (6): 681-683.

Dhore, K. R. (2011). Sensory evaluation of sorghum chakli enriched with different levels of soybean flours. Journal of International Reference 3: 50-51.

Geethalakshmi, V. and Prakash, J. (2000). Processing variables and quality Parameters of chakli- an Indian traditional deep fried product. Journal of Food Science and Technology, 37:227-232.

Hassid, Abraham. (1965). Methods in Enzymology. Indian Engineering Chemistry Analysis 9:288.

Kulkarni, S. G. Mannan, J. K. and Shukla, J. C. (1994). Studies on the deep fat fried sevian made from rice flour and colocasia. Journal of Food Science and Technology 31(3): 207-210.

Nath, J. P. and Narsing, Rao, M. S. (1981). Functional properties of gaur protein. Journal of Food Science 46: 12-55.

Panse, V. G. and Sukhamte, P. V. (1963). Statistical methods for agricultural workers, Indian council for agricultural research, New Delhi, India.

Pruthi, J. S. Kalra, C. L. Manan, J. K. and Raina, B. L. (1983). The manufacture, packaging and storage of traditional savoury foods, parts II. Phulwadian, mukandawadian and other savoury foods. Indian food packer, 37(6): 73-94.

Rachie, K. O. (1975). The millets: importance, utilization and outlook. International Crop Research Institute for the Semi-Arid Tropics, Hyderabad p 1-2.

Senthil, A. Ravi, R. Bhat, K. K. and Seethalakshmi M. K. (2002). Studies on the quality of fried snacks based on blends of wheat flour and soya flour. Food Quality and Preference, 13 (5): 267-273.

Singh, J. K. Azeem, Z. and Singh, S. S. (2003). Comparative studies on extruded snacks food with keshri dhal and chickpea flour. Journal of Food Science and Technology, 40 (3): 333-336.

Singh, U. and Seetha, R. (1994). Oil absorption and sensory properties of a snack food from chickpea genotypes. Journal of Food Science, 58 (4): 853-855.

Sosulski, F. W. Humbert, E. S. Bui, K. and Jones, J. D. (1976). Journal of Food Science 41:134.

Tasneem, R. Ramamani, S. and Subramanian, N. (1982). Functional properties of guar seed meal detoxified by different methods. Journal of Food Science and Technology 47:1175.

Veena, B. Chimmand, B. V. Naik, R. K. and Shanthakumar, G. (2005). Physichemical and nutritional studies in millet. Karnataka Journal of Agricultural Sciences 18 (1): 101-105. 